\title{
Dentinal Tubule Occlusion with Lanthanum Fluoride and Powdered Apatite Glass Ceramics in vitro
}

\author{
Yoshiharu MUKAI, Kiyoshi TOMIYAMA, Shusaku OKADA, \\ Katsumi MUKAI, Hideyuki NEGISHI ${ }^{1}$, Tsutomu FUJIHARA ${ }^{1}$ \\ and Toshio TERANAKA \\ Department of Operative Dentistry and Endodontics, \\ and ${ }^{1}$ Dental Biotechnology and Bioengineering, \\ Kanagawa Dental College, Yokosuka, 238-8580, Japan
}

Received May 25, 1998/Accepted September 10, 1998

\begin{abstract}
To simulate hypersensitive dentin, the smear layer and dentinal plugs of bovine root dentin specimens were removed by immersion in $10 \%$ phosphoric acid, polishing with hydroxyapatite particles, and ultrasonic cleansing. The fluoride-tannic acid-lanthanum-apatite (FTLA) group was treated with acidulated phosphate fluoride (APF) containing tannic acid followed by rubbing with a paste of lanthanum chloride $\left(\mathrm{LaCl}_{3}\right)$ and powdered apatite glass ceramics. The treated specimens were immersed in a remineralizing solution that mimics saliva for 6 weeks. The SEM observations revealed that the treated surfaces of the FTLA group were completely covered with fine spherical compounds and the dentinal tubules were occluded with plugs to a depth of about $3 \mu \mathrm{m}$. Fluoride and lanthanum were detected to a depth of over $20 \mu \mathrm{m}$ by EPMA observation. After the remineralization, the surface of FTLA-treated specimen did not have any opened tubules and showed a remarkable increase in the number of fine spherical deposits in the dentinal tubules. These results suggest that the reaction products produced by sequential treatment with acidic fluoride and $\mathrm{LaCl}_{3}$ and powdered apatite glass ceramics are able to effectively occlude dentinal tubules.
\end{abstract}

Key words: Dentin hypersensitivity, Lanthanum fluoride, Powdered apatite glass ceramics

\section{INTRODUCTION}

The pain induced in hypersensitive dentin can be extremely intense and may present a considerable problem in daily life. The hydrodynamic theory is generally accepted as the most reasonable explanation for the mechanism of action of dentin hypersensitivity. An increased number of exposed dentinal tubules increases the potential for dentinal fluid flow, which is directly responsible for the patients' discomfort ${ }^{1)}$. A corollary of this theory is that tubular occlusion would thus decrease dentin hypersensitivity ${ }^{2}$. Indeed, significant differences in the opening of dentinal tubules have been reported between hypersensitive and naturally desensitized areas ${ }^{3,4}$. Various techniques and agents have been reported to be effective for dentinal tubule occlusion, e.g., potassium oxalate ${ }^{2,5,6)}$, sodium fluoride ${ }^{7)}$, ferric oxalate ${ }^{8)}$, and resins ${ }^{9,10)}$. Combined potassium oxalate treatment (2-min of a solution containing $30 \%$ dipotassium oxalate followed by 2 -min treatment of a solution containing $3 \%$ monopotassiummonohydrogen oxalate) has been recommended as an effective treatment for dentin 
hypersensitivity based, at least in part, on calcium oxalate precipitation in the dentinal tubules ${ }^{2,5,11)}$.

We previously reported that a treatment with acidulated phosphate fluoride (APF) followed by a lanthanum chloride $\left(\mathrm{LaCl}_{3}\right)$ solution (fluoride-lanthanum treatment, F-La treatment) formed insoluble amorphous deposits containing lanthanum as one of the reaction products on the dentin surfaces and that this increased the resistance of the root dentin to acid attack ${ }^{12,13)}$. Further, when this treatment was used on dentin surfaces on which smear layers and plugs had been dissolved to simulate hypersensitive dentin, the surface was completely covered with fine spherical compounds ${ }^{14)}$. However, the durability of tubule occlusion was questionable because this material did not include filler components that will firmly occlude dentinal tubules. A newly developed treatment, designated as fluoride-tannic acid-lanthanum-apatite (FTLA) treatment consists of the application of APF containing tannic acid, followed by rubbing with a paste of $\mathrm{LaCl}_{3}$ solution and powdered apatite glass ceramics.

In the present study, we examined the feasibility of FTLA treatment for dentinal tubule occlusion before and after immersion in a remineralizing buffer in vitro.

\section{MATERIALS AND METHODS}

Manufacturing process and the composition of powdered apatite glass ceramics Powdered apatite glass ceramic is a material for dentinal tubule occlusion (Taihei Chemical Industrial Co., Ltd., Osaka, Japan). Powders $\left(\mathrm{CaCO}_{3}, \mathrm{CaHPO}_{4}, \mathrm{SiO}_{2}\right.$, $\mathrm{Al}(\mathrm{OH})_{3}, \mathrm{Mg}(\mathrm{OH})_{2}$ and $\left.\mathrm{CaF}_{2}\right)$ were mixed and heated to $1,000^{\circ} \mathrm{C}$ (heating rate of about $200^{\circ} \mathrm{C} / \mathrm{hr}$ ), and cooled to room temperature. After cooling, the powder was melted at $1,550^{\circ} \mathrm{C}$ for 30 minutes, and quenched to room temperature for crystallization. The apatite glass ceramic was then crushed to an average particle size of $0.87 \mu \mathrm{m}$ (data supplied by manufacturer). The component of the powdered apatite glass ceramics is shown in Table 1.

Sample preparation and dentin specimens treatment (Fig. 1)

Six bovine lower incisors at the mixed-dentition stage were obtained from a meatpacking plant. Dental pulp, cementum, periodontal ligament and other adherent soft tissues were removed with a curette. The crowns were separated at the cementumenamel junction (CEJ); the roots were used for these experiments. To prepare dentin specimens, the roots were cut perpendicular to the longitudinal axis about $5 \mathrm{~mm}$ thick

Table 1 Powdered apatite glass ceramics

\begin{tabular}{ll} 
Components & $\mathrm{CaO}: 38.5 \mathrm{wt} \% ; \mathrm{P}_{2} \mathrm{O}_{5}: 14.3 \mathrm{wt} \% ; \mathrm{SiO}_{2}: 22.6 \mathrm{wt} \% ;$ \\
& $\mathrm{MgO}: 0.5 \mathrm{wt} \% ; \mathrm{Al}_{2} \mathrm{O}_{3}: 19.1 \mathrm{wt} \% ; \mathrm{F}_{2} ; 5.0 \mathrm{wt} \%$ \\
Shape & White powder \\
& \\
Ave. particle size & $0.87 \mu \mathrm{m}$ \\
\hline
\end{tabular}




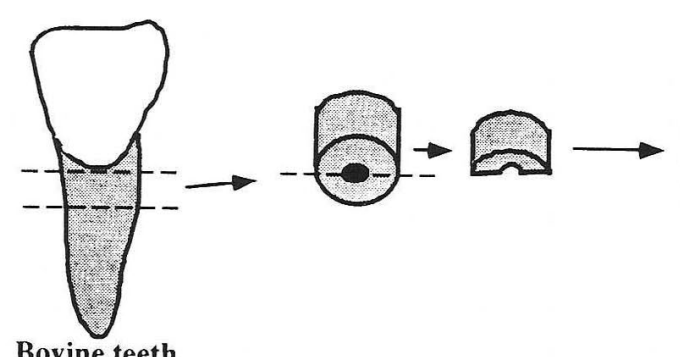

Bovine teeth

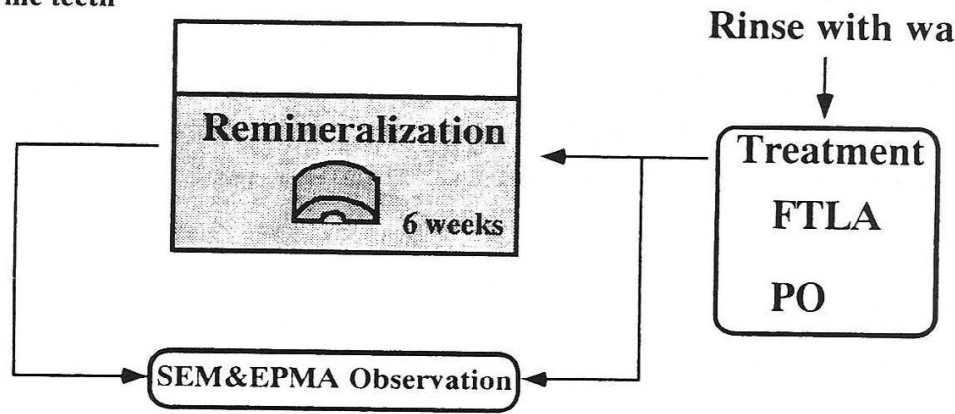

Fig. 1 The procedure of specimen preparation and dentin treatment.

below the CEJ with the use of water-cooled carbide burs. The cylindrical specimens were then vertically sectioned into two halves (Fig.1). To obtain a flat root surface, the dentin surface was planed by curettage. To simulate hypersensitive dentin, prepared dentin specimens were immersed in a $10 \%$ phosphoric acid solution for 10 seconds followed by polishing for one minute with $0.1 \mathrm{~g}$ of a hydroxyapatite paste on a bristle brush (Clover Brush, Satoushizai, Tokyo, Japan) rotating at 1,000 rpm using a low-speed hand piece. The polishing paste was composed of $30 \%$ hydroxyapatite particles (Avg. particle size : 100-200 $\mu \mathrm{m}$, Taihei Chemical Industrial Co., Ltd, Osaka, Japan), 49\% propylene glycol (Wako, Osaka, Japan), and 21\% polyvinyl pyrrolydone (MW, 40,000; Wako, Osaka, Japan $)^{15)}$. The surfaces were then washed with water and placed in $10^{\circ} \mathrm{C}$ de-ionized water in an ultrasonic cleaner (Bransonic B3200, EMERSONJAPAN, Tokyo, Japan; output power, 120 Watts, Freq., $47 \mathrm{kHz}$ ) for 35 minutes for removal of sticky residual contaminants and smear plugs. After rinsing with deionized water, these dentin specimens were divided into three groups (control, potassium oxalate, and FTLA group, $\mathrm{n}=1$ ).

The control group was untreated. In the FTLA group, the surface was treated with $50 \mathrm{mg}$ of $\mathrm{APF}(2.2 \mathrm{w} / \mathrm{v} \% \mathrm{NaF}$ in $1 \mathrm{w} / \mathrm{v} \%$ phosphoric acid, $\mathrm{pH} 3.4)$ containing $5 \mathrm{w} / \mathrm{v} \%$ tannic acid for three minutes using cotton pellet, after which the specimens were dried by a gentle air stream and then treated with a paste consisting of $50 \mathrm{mg}$ of $1.8 \mathrm{w} / \mathrm{v} \% \mathrm{LaCl}_{3}(\mathrm{pH} 4.3)$ and $5 \mathrm{mg}$ of powdered apatite glass ceramics for three minutes beginning with a 15 -second scrub with a cotton pellet. The combined potassium oxalate group (PO group) was treated with a solution containing $30 \mathrm{w} / \mathrm{v} \%$ dipotassium oxalate $(\mathrm{pH} \mathrm{7.0)}$ for two minutes, wiped dry, and then treated with a 
solution containing $3 \mathrm{w} / \mathrm{v} \%$ monopotassium-monohydrogen oxalate $(\mathrm{pH} 2.0$ ) for two minutes $^{16)}$. One half of the specimens were then immediately analyzed with SEM and an electron probe microanalyzer (EPMA), while the other half of the PO- and FTLAtreated specimens were immersed in a remineralizing buffer (1.0 wt\% carboxymethyl cellulose, $3.0 \mathrm{mM} \mathrm{Ca}, 1.8 \mathrm{mM} \mathrm{P}, \mathrm{pH} 7.0)^{17-19)}$ for 6 weeks at $37^{\circ} \mathrm{C}$. All of the specimens were then split longitudinally into halves. Half were used for observation of the dentin surface and the other half were used as cross sections for the observation of insides of dentinal tubules. These specimens were air-dried at room temperature, then further dried in a vacuum for 12 hours and sputter-coated with gold for SEM observation (JSM-820, JEOL, Tokyo, Japan) at $5 \mathrm{kV}$. An elemental analysis of the split surfaces was performed with EPMA with an accelerating voltage of $20 \mathrm{kV}, 10 \mu \mathrm{s} /$ point, $512 \times 512$ points on a $20 \times 20 \mu \mathrm{m}$ (EPMA-8705, Shimadzu, Kyoto, Japan).

\section{RESULTS}

Figure 2 shows the SEM appearance of a simulated hypersensitive dentin specimen prior to receiving any treatment. The smear layers were removed and most of the dentinal tubules were opened. The surfaces of the FTLA-treated specimens were completely covered with fine spherical compounds, and the dentinal tubules were occluded with materials to a depth of about $3 \mu \mathrm{m}$ (Fig. 3 ). After soaking in a remineralization
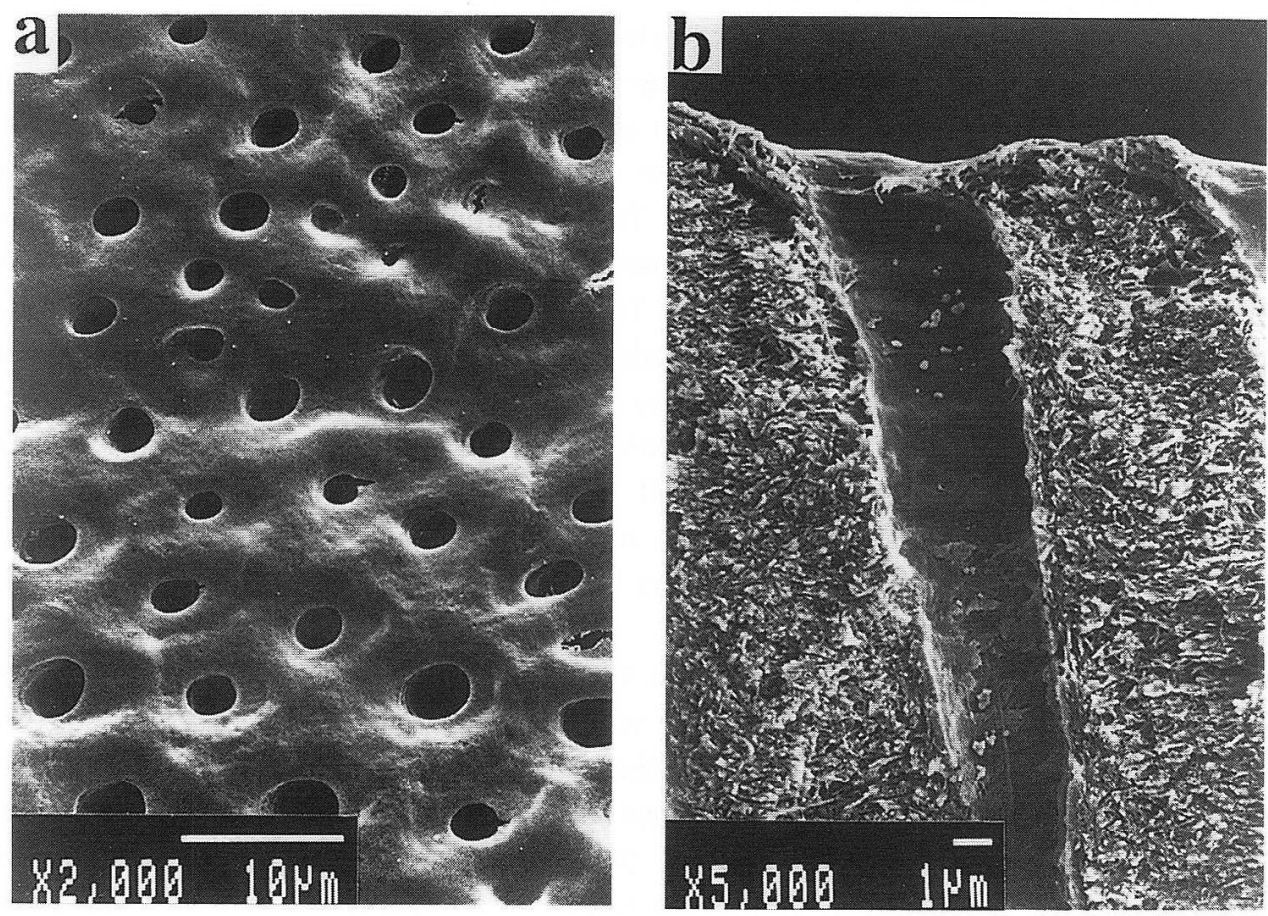

Fig. 2 Scanning electron micrographs of a specimen simulating dentin hypersensitivity before treatment (a: surface, b: split surface). 

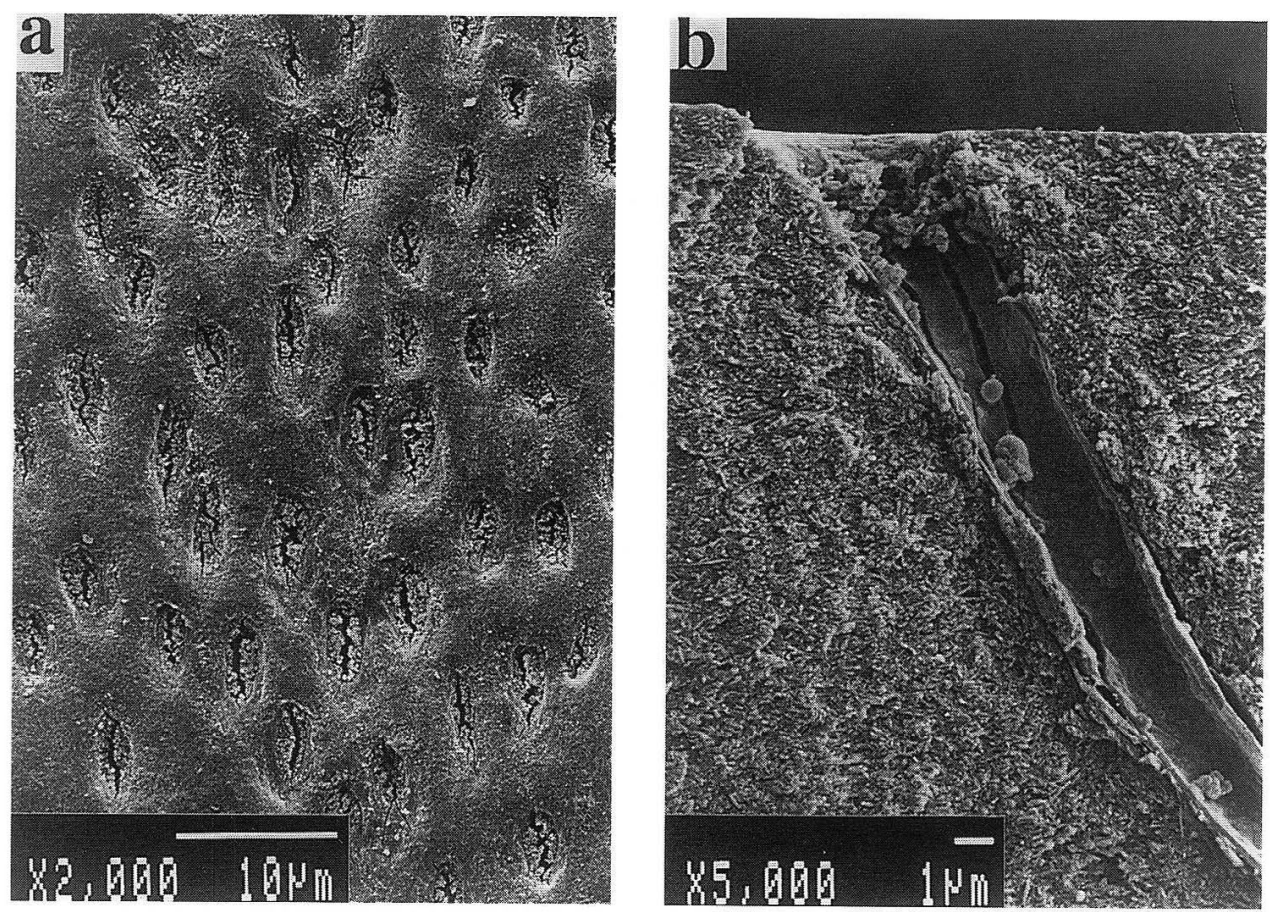

Fig. 3 Scanning electron micrographs of a specimen treated with the FTLA method. The treated surface was completely covered with fine spherical compounds (a: surface, b: split surface).

buffer for 6 weeks, the FTLA specimens showed an increase in the number of fine spherical deposits in the dentinal tubules (Fig. 4). Immediately after PO-treatment, the precipitate was occluded in the dentinal tubules and intertubular dentin, but some tubules were open (Fig. 5). Most of the tubules were opened after the full 6 weeks' immersion (Fig. 6).

Specimens examined by EPMA immediately after FTLA treatment are shown in the top three panels labeled "a". Specimens examined after soaking in the remineralizing buffer for 6 weeks are shown in the lower panels labeled " $b$ ". The EPMA examination of the fractured edge of FTLA-treated specimens revealed that aluminum ( $\mathrm{Al}$ ) was detected at a depth of about $3 \mu \mathrm{m}$ (Fig. 7). Fluoride (F) and lanthanum (La) were detected at depths of over $20 \mu \mathrm{m}$. After the immersion in remineralizing buffer for 6 weeks, $\mathrm{F}$ was slightly decreased in the content and diffused into the intertubular dentin, but $\mathrm{Al}$ and La were detected at levels similar to those measured before the remineralization (Fig. 7).

\section{DISCUSSION}

To simulate hypersensitive dentin, the smear layer can be removed by the use of various agents (0.5 M EDTA for two $\min ^{16)}$, $0.6 \mathrm{M} \mathrm{HCl}$ for one $\min ^{20,21)}$, $50 \%$ citric acid for 

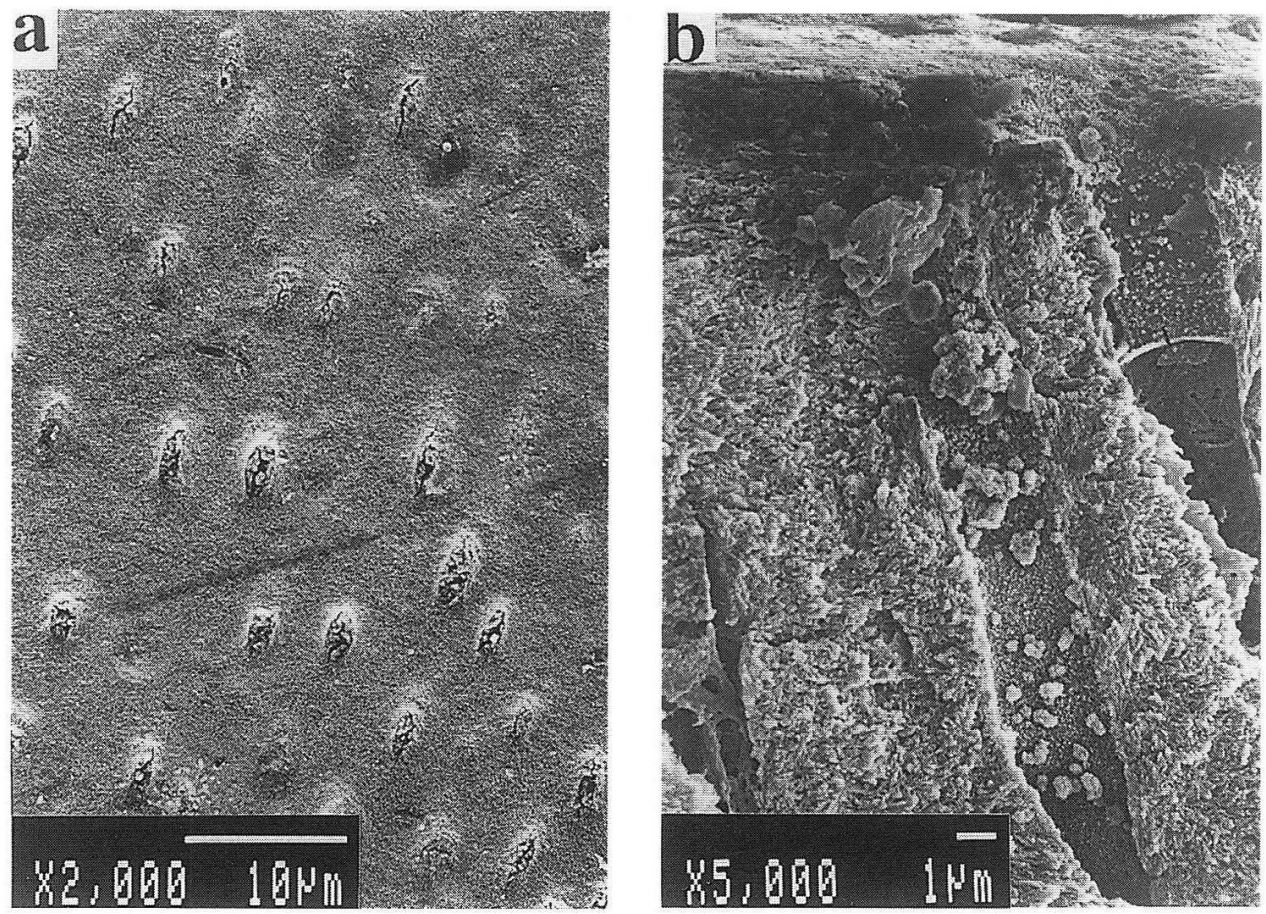

Fig. 4 Scanning electron micrographs of a specimen treated with the FTLA method after immersion in the remineralizing solution for 6 weeks. An increase in the number of fine deposits was detected in the dentinal tubules (a: surface, b: split surface).

two $\min ^{22)}$ ). However, such agents result in various degrees of smear layer removal and seem to produce excessive demineralization of the root surface. Loss of enamel, dentin and a subsequent increase in dentin sensitivity may occur from combinations of attrition, abrasion or erosion ${ }^{23-25)}$. Therefore, in the present study, the dentin surface was demineralized slightly using $10 \%$ phosphoric acid solution for 10 seconds followed by polishing for one minute with a hydroxyapatite paste.

When dentin disks were treated with a solution containing $25 \%$ potassium oxalate, the dentin permeability decreased immediately, but it increased gradually after immersion in synthetic saliva at $37^{\circ} \mathrm{C}^{22}$. Pashley reported that the combined oxalate treatment produced lower dentin permeability than a treatment using $30 \%$ potassium oxalate solution $^{6)}$. This treatment effectively diminishes the hypersensitivity in the early stage; however, its effect is reported to be relatively short-lived, possibly due in part to the high solubility of calcium oxalate ${ }^{16)}$. In our present study, the SEM observation revealed that most of the precipitate formed by the PO treatment was dissolved during the 6 week immersion period at $37^{\circ} \mathrm{C}$. This result supports the findings of previous studies ${ }^{16,22)}$.

The dissolution of enamel is reduced by the treatment with chlorides of several rare elements ${ }^{26)}$. There are some indications that lanthanum nitrate $\left(\mathrm{La}\left(\mathrm{NO}_{3}\right)_{3}\right)$ may 

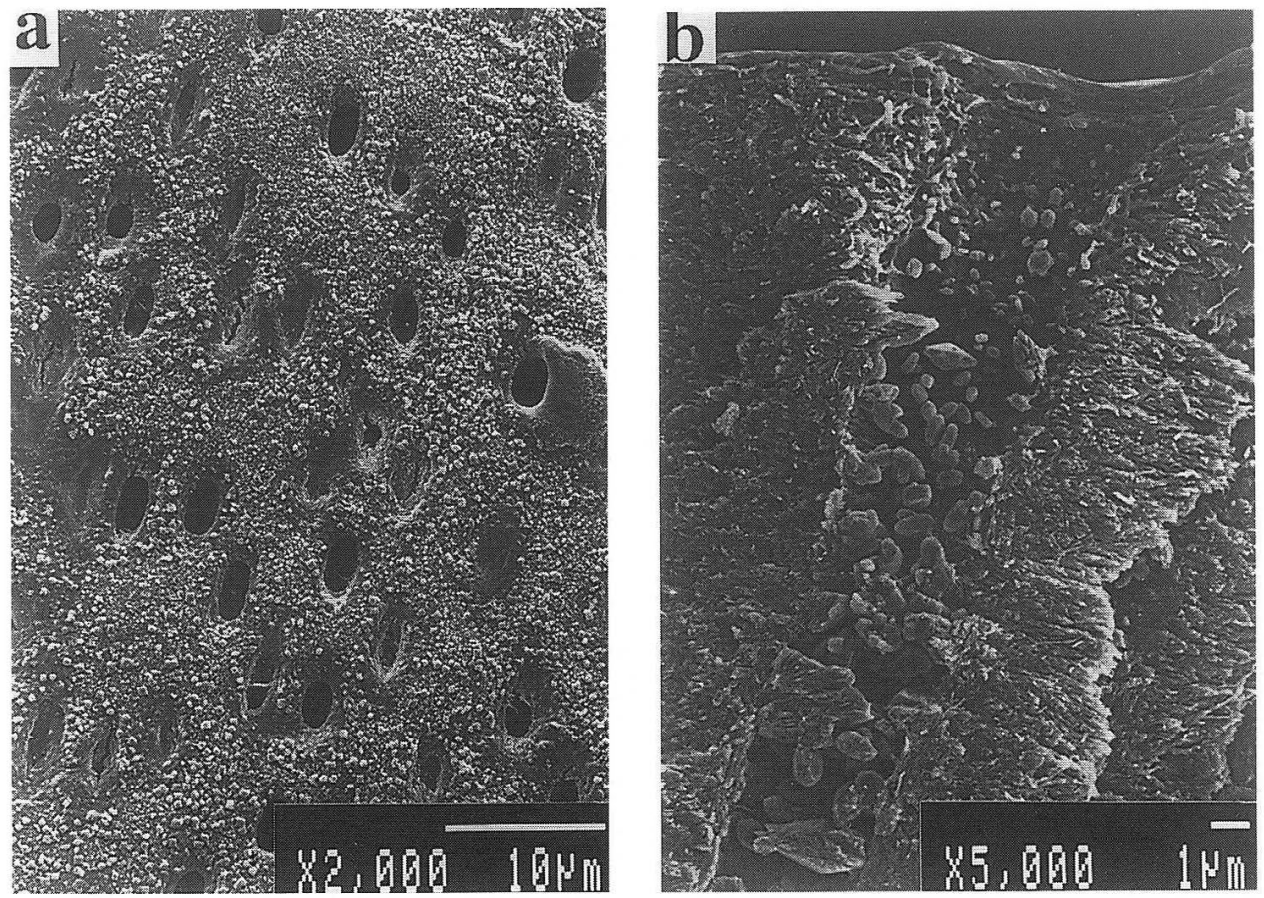

Fig. 5 Scanning electron micrographs of a specimen treated with potassium oxalate. The dentinal tubules were partially occluded (a: surface, b: split surface).

contribute to the prevention of caries $^{27,28)}$. The adherence of Streptococcus mutance to teeth was markedly inhibited by treatment with $\mathrm{La}\left(\mathrm{NO}_{3}\right)_{3}{ }^{29)}$. When enamel was treated with $\mathrm{La}\left(\mathrm{NO}_{3}\right)_{3}$, calcium and phosphate were less dissolved from the teeth ${ }^{30)}$. Based on these findings and the low toxicity of $\mathrm{La}\left(\mathrm{NO}_{3}\right)_{3}{ }^{27)}$, we have been investigating the usefulness of lanthanum and its chlorides. Using a low concentration and short application time (5-10 minutes) of $\mathrm{LaCl}_{3}$, the solubility of apatite powder did not decrease; indeed F-La treatment markedly decreased its solubility ${ }^{31)}$. On the dentin surface, $\mathrm{LaF}_{3}$ was efficient as a barrier against acid attack ${ }^{12,13}$.

In the FTLA method, $\mathrm{LaF}_{3}$, lanthanum phosphate, and calcium fluoride may be generated as reaction products in the same manner as F-La treatment on the dentinal surface and in the dentinal tubules, and powdered apatite glass ceramics may serve as a filler within the reaction products that precipitate within the dentinal tubules. Presumably, application of acidic solutions of fluoride followed by a paste of $\mathrm{LaCl}_{3}$ produced insoluble reaction products such as $\mathrm{LaF}_{3}$ which, combined with powdered apatite glass ceramics, contributed to the immediate occlusion of dentinal tubules. Tannic acid, added in APF, may act as an astringent and form stable cross-links in exposed collagen fibrils thereby increasing their resistance to hydrolytic degradation $^{32)}$. After immersion, we detected that the number of fine deposits had increased remarkably in the dentinal tubules (Fig. 4). The profile of fluoride release from paste 

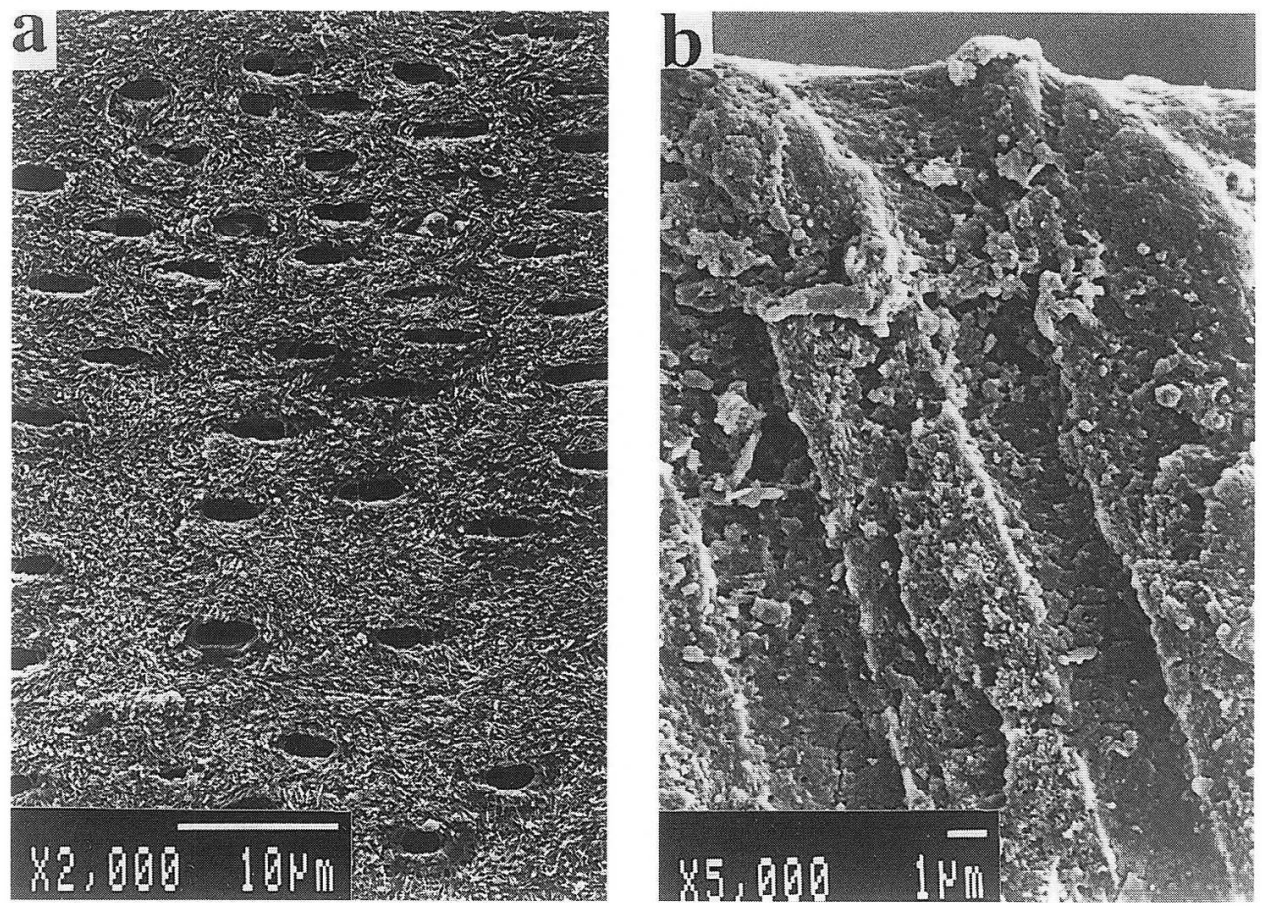

Fig. 6 Scanning electron micrographs of a specimen treated with potassium oxalate after immersion in the remineralizing solution for 6 weeks. Most of the tubules were opened (a: surface, b: split surface).

following FTLA treatment (powdered apatite glass ceramic, APF containing tannic acid and $\mathrm{LaCl}_{3}$ ) throughout the 6 week period was similar to that of fluoride release by a glass polyalkenoate cement. However, cumulative fluoride release from the powdered apatite glass ceramic was somewhat more than that of glass polyalkenoate cement ${ }^{33)}$. These fluoride compounds may also act as a reservoir for fluoride and contribute to the growth of hydroxyapatite and fluoridated apatite in dentinal tubules when combined with calcium and phosphate from saliva and pulpal/dentinal fluid $^{34-36)}$. The crystals may shift to fluorapatite gradually because of the slow relcase of fluoride over a long period of time.

We conclude that FTLA treatment offers not only an immediately effective treatment for dentin hypersensitivity but may also maintain the tubule occlusion in the oral environment over at least 6 weeks. However, tooth-brush abrasion test and clinical trials should be conducted to estimate the durability of tubule occlusion.

\section{ACKNOWLEDGMENTS}

The authors express their thanks to Taihei Chemical Industrial Co., Ltd. (Osaka, Japan) for providing the powdered apatite glass ceramics. 
a
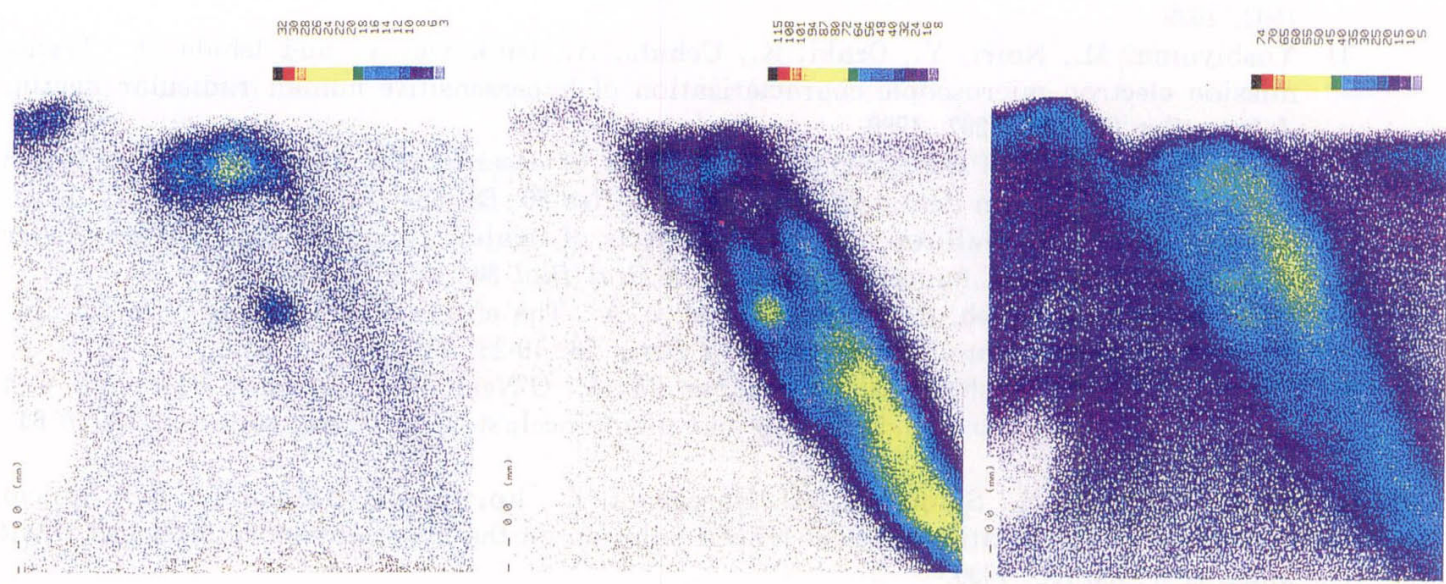

b

หม่
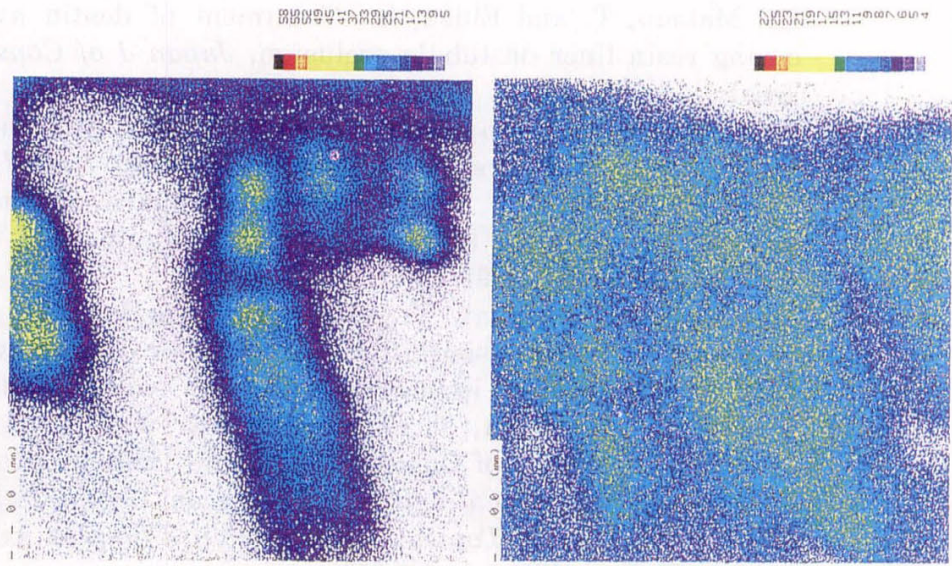

$\mathrm{Al}$

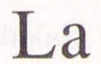

$\mathrm{F}$ $10 \mu \mathrm{m}$

Fig. 7 Electron probe micro analysis of a specimen treated with the FTLA method before (a) and after (b) immersion in remineralizing solution for 6 weeks. The dentinal tubules were occluded to a depth of about $3 \mu \mathrm{m}$ with fluorapatite glass particles containing $\mathrm{Al}$ and over 20 $\mu \mathrm{m}$ with $\mathrm{F}$ and $\mathrm{La}(\mathrm{a})$. F was slightly dissolved and diffused into the intertubular dentin, but $\mathrm{Al}$ and La were detected in the dentinal tubules at levels similar to those before remineralization (b).

\section{REFERENCES}

1) Brännström, M.: Sensitivity of dentine, Oral Surg, Oral Med and Oral Pathol 21 : 486-488, 1966.

2) Pashley, D. H.: Dentin permeability, dentin sensitivity, and treatment through tubule occlusion, J Endo $12: 465-474,1986$.

3) Yoshiyama, M., Masuda, J., Uchida, A. and Ishida, H.: Scanning electron microscopic characterization of sensitive vs. insensitive human radicular dentin, $J$ Dent Res 68 : 1498- 
$1502,1989$.

4) Yoshiyama, M., Noiri, Y., Ozaki, K., Uchida, A., Ishikawa, Y. and Ishida H.: Transmission electron microscopic characterization of hypersensitive human radicular dentin, J Dent Res 69 : 1293-1297, 1990.

5) Greenhill, J.D. and Pashley, D. H.: The effects of desensitizing agents on the hydraulic conductance of human dentin in vitro, $J$ Dent Res $60: 686-698,1981$.

6) Pashley, D. H. and Galloway, S. E.: The effects of oxalate treatment on the smear layer of ground surfaces of human dentine, Arch Oral Biol 30 : 731-737, 1985.

7) Pashley, D. H., Leibach, J.G. and Horner, J. A.: The effects of burnishing NaF/Kaolin/ Glycerin paste on dentin permeability, J Perio 58:19-23, 1987.

8) Dragolich, W. E., Pashley, D. H., Brennan, W. A., O'Neal, R. B., Horner, J. A. and Van Dyke, T. E.: An in vitro study of dentinal tubule occlusion by ferric oxalate, $J$ Perio 64 : 1045-1051, 1993.

9) Suda, R., Ando, Y., Shionome, M., Hasegawa, K., Ito, K. and Wakumoto, S.: Clinical evaluation of the sedative effect of HEMA solution on the hypersensitivity of dentin, Dent Mater $J$ 9: 163-166, 1990.

10) Yoshiyama, M., Ozaki, K., Noiri, Y., Kataoka, K., Nakanishi, T., Ogimoto, R., Nakae, H., Matsuo, T. and Ebisu, S.: Treatment of dentin hypersensitivity. Effect of a lightcuring resin liner on tubule occlusion, Japan $J$ of Conserv Dent 34:76-81, 1991. (in Japanese)

11) Reeder, O. W., Walton, R. E., Livingston, M. J. and Pashley, D. H.: Dentin permeability: Determinants of hydraulic conductance, $J$ Dent Res $57: 187-193,1978$.

12) Teranaka, T., Mukai, Y., Negishi, H., Fujihara, T. and Iwamoto, T.: Effect on root surface demineralization treated with fluoride-lanthanum, $J$ Dent Res 70 (Special issue) : 308 (Abstract No.337), 1991.

13) Tomiyama, K., Mukai, Y., Okada, S., Negishi, H., Fujihara, T., Teranaka, T. and Iwamoto, T.: Acid resistibility of root dentin treated with fluoride-lanthanum in vitro, $J$ Dent Res 73 (Special issue) : 338 (Abstract No.1891), 1994.

14) Mukai, Y., Teranaka, T., Tomiyama, K., Okada, S., Negishi, H., Fujihara, T. and Iwamoto, T.: Effect of fluoride-lanthanum treatment for dentin hypersensitivity. In Proceedings of the International Conference on Dentin/Pulp Complex and the International Meeting on Clinical Topics of Dentin/Pulp Complex, ed. M. Shimono. Quintessence Publishing, Tokyo, 1996, pp.248-250.

15) Saito, Y., Hotta, K., Soma, R. and Nakabayashi, N.: Effect of phosphoric acid concentration on adhesion to polished human enamel surface, $J J$ Dent Mater 12 : 418-423, 1993. (in Japanese)

16) Kerns, D. G., Scheidt, M. J., Pashley, D. H., Horner, J. A., Strong, S. L. and Van Dyke T. E.: Dentinal tubule occlusion and root hypersensitivity, J Perio 62 : 421-428, 1991.

17) Inaba, D. and Takagi, O.: Changes in mineral volume in root surfaces during early stage of remineralization: Evaluation by a single-section and videodensitometric method, $J$ Dent Health 42 : 393-398, 1992. (in Japanese)

18) Inaba, D., Iijima, Y. and Takagi, O.: Influence of human saliva induced pellicle on remineralization in root surfaces, $J$ Dent Health $42: 496-497,1992$. (in Japanese)

19) Inaba, D. and Takagi, O.: The reaction patterns of enamel and root dentine samples after demineralization and remineralization, J Dent Health $46: 290-296,1996$. (in Japanese)

20) Ishikawa, K., Suge, T., Yoshiyama, M., Kawasaki, A., Asaoka, K. and Ebisu, S.: Occlusion of dentinal tubules with calcium phosphate using acidic calcium phosphate solution followed by neutralization, J Dent Res $73: 1197-1204,1994$.

21) Suge, T., Ishikawa, K., Kawasaki, A., Yoshiyama, M., Asaoka, K. and Ebisu, S.: Effects of fluoride on the calcium phosphate precipitation method for dentinal tubule occlusion, J Dent Res 74:1079-1085, 1995.

22) Suge, T., Ishikawa, K., Kawasaki, A., Yoshiyama, M., Asaoka, K. and Ebisu, S.: 
Duration of dentinal tubule occlusion formed by calcium phosphate precipitation method: in vitro evaluation using synthetic saliva, J Dent Res $74: 1709-1714,1995$.

23) Pashley, D. H.: Dentine permeability and its role in the pathology of dentine sensitivity, Arch Oral Biol 39 (Special issue) : 73S-80S, 1994.

24) Mannerberg, B. S.: Changes in the enamel surface in cases of erosion - A replica study, Arch Oral Biol 4:59-62, 1961.

25) Sognnaes, R.F.: Dental hard tissue destruction with special reference to idiopathic erosions. In mechanisms of hard tissue destruction, ed. Sognnaes R. F. American association for advancement of science, Washington, 1963, pp.91-149.

26) Shrestha, B. M., Mundorff, S. A. and Bibby, B. G.: Enamel dissolution: I. Effects of various agents and titanium tetrafluoride, $J$ Dent Res $51: 1561-1566,1972$.

27) Ozeki, M., Kobayashi, Y., Takei, M. and Shimano, R.: Inhibition of dentinal caries by lanthanum, $J$ Dent Health $28: 449-454$, 1979. (in Japanese)

28) Shimano R.: A fundamental study on lanthanum as a preventive of dental caries, $J$ Dent Health $29: 361-377,1980$. (in Japanese)

29) Ozeki, M.: Relative changes of the oral microflora in the induction and the lanthanum inhibition of dental caries in rats, Aichi-Gakuin J Dent Science 19:364-398, 1982. (in Japanese)

30) Kobayashi, Y., Ozeki, M., Yagi, T., Hosoi, T. and Takei, M.: Aciduric resistance of lanthanum-treated teeth, $J$ Dent Health $30: 388-402$, 1980. (in Japanese)

31) Fujihara, T., Negishi, H., Yamazaki, N., Miyagi, A., Higaki, M. and Saito, S.: Insolubilization of teeth by fluoride-lanthanum treatment, Japan J Oral Biol 26 : 454-460, 1984. (in Japanese)

32) Okamoto, Y., Heeley, J. D., Dogon, I. L. and Shintani, H.: Effects of phosphoric acid and tannic acid on dentine collagen, J Oral Rehab 18:507-512, 1991.

33) Tomiyama, K., Mukai, Y., Okada, S., Teranaka, T., Negishi, H., Fujihara, T., Kawase, T. and Ueda, M.: Application of fluoride-lanthanum treatment to conservative dentistry (VII). Durability as a treatment agent for dentin hypersensitivity, Japan $J$ Conserv Dent 40 (Autumn issue) : 85, 1997. (in Japanese)

34) ten Cate, J.M. and Duijsters, P. P. E.: The influence of fluoride in solution on tooth demineralization, I. chemical data, Caries Res $17: 193-199,1983$.

35) Moreno, E. C. and Zahradnik, R. T.: Chemistry of enamel subsurface demineralization in vitro, J Dent Res $53: 226-235,1974$.

36) Schupbach, P., Lutz, F. and Guggenheim, B.: Human root caries, histopathology of arrested lesions, Caries Res 26 : 153-164, 1992. 